\title{
Establishment of Real-Time Fluorescent PCR Method for Detection of D Epizootic Hemorrhagic Disease of Deer
}

\author{
Bin $\mathrm{Wu}^{1}$, Chao Wan 1 , Liming Su${ }^{2}$, Peng Guan ${ }^{2}$ \\ ${ }^{1}$ Dalian Customs Co., Ltd., Dalian, China \\ ${ }^{2}$ China Certification Group Liaoning Co., Ltd., Dalian, China \\ Email: wubin69@163.com
}

How to cite this paper: Wu, B., Wan, C., Su, L.M. and Guan, P. (2018) Establishment of Real-Time Fluorescent PCR Method for Detection of D Epizootic Hemorrhagic Disease of Deer. Advances in Microbiology, 8, 476-481.

https://doi.org/10.4236/aim.2018.87032

Received: April 3, 2018

Accepted: July 23, 2018

Published: July 26, 2018

Copyright $\odot 2018$ by authors and Scientific Research Publishing Inc. This work is licensed under the Creative Commons Attribution International License (CC BY 4.0).

http://creativecommons.org/licenses/by/4.0/

\begin{abstract}
Epizootie hemorrhagic disease of deer virus (EHDV), is a member of the family Reoviridae virus (Orbi virus), and a double-stranded RNA virus from arthropods (mainly Culicoides), which is very similar in morphology and structure to Blue tongue virus (BTV). Serologically, there is a clear cross between the blue tongue virus and EHDV. EHD (caused by EHDV) is a seasonal, non-contact viral infectious disease. Under natural conditions, EHDV can cause infection of cattle, sheep and other domestic animals as well as many domesticated and wild ruminants such as white tail deer, Mi, large horned antelope and so on. The virus has been isolated from white-tailed deer, black-tailed deer, sheep, goats, cattle, bison and Culicoides. White tail deer infection is the most serious, and clinical characteristics are transient elevated body temperature, symptoms of shock, mucosal, serous bleeding and death in a coma [1]. At present, there is no effective vaccine and treatment for this disease. To control and eliminate EHD, it is necessary to spend a lot of manpower and material resources. Export trade is restricted, which brings great economic losses to the countries with EHD epidemic. Moreover, because of the complexity of antigen structure and the diversity of clinical symptoms of EHDV, it is difficult to diagnose in laboratory. Therefore, developing a quick and precise laboratory diagnostic method becomes more and more significant among researchers.
\end{abstract}

\section{Keywords}

Loop-Mediated 


\section{Materials and Methods}

\subsection{Reagent}

DEPC water, $0.01 \mathrm{~mol} / \mathrm{L}$ PBS, Trizol lysate, trichloromethane, 75\% ethyl alcohol, isopropyl alcohol $\left(-20^{\circ} \mathrm{C}\right.$ precooling), other reagents are analytical pure, and grade- 1 water as required by GB/T 6682 . All reagents are separated by containers without RNA.

By consulting the data and nucleic acid sequence of GenBank, the specific primers and probes were designed and synthesized for the gene sequence of EHDV:

Forward primer 5'-GCGTTGGATATATTGGACAAAGC-3';

Reverse primer 5'-GCATACGAAGCATAAGCAACCTT-3'.

TaqMan probe FAM-TCAAATCAAACGGGCGCAACTATGG-BGH, made into $5 \mathrm{umol} / \mathrm{L},-20^{\circ} \mathrm{C}$. All are synthesized by Bao biologic engineering (Dalian) Co., Ltd.

\subsection{Equipment}

Fluorescent PCR detector, high-speed refrigerated centrifuge (the maximum can be $13,000 \mathrm{r} / \mathrm{min})$, micropipettor $(0.5 \mu \mathrm{L}-10 \mu \mathrm{L}, 5 \mu \mathrm{L}-20 \mu \mathrm{L}, 20 \mu \mathrm{L}-200 \mu \mathrm{L}, 100$ $\mu \mathrm{L}-1000 \mu \mathrm{L})$, refrigerator $\left(2^{\circ} \mathrm{C}-8^{\circ} \mathrm{C}\right)$, etc.

\subsection{Sample Collection and Processing}

Pretreatment of blood samples: take $2 \mathrm{~mL}$ of whole blood sample, $3000 \mathrm{~g}$ centrifugation for $10 \mathrm{~min}$ at $4^{\circ} \mathrm{C}$, abandon precipitation, collect supernatant and extract nucleic acid.

Pretreatment of tissue samples: take $100 \mathrm{mg}$ tissue sample and cut into pieces, add $0.01 \mathrm{~mol} / \mathrm{L} \mathrm{Ph}$ 7.6PBS by 1:5, repeat freezing and thawing for three times after grinding, centrifuge for $10 \mathrm{~min}$ at $4^{\circ} \mathrm{C} 3000 \mathrm{~g}$ and take the supernatant, preserve at the temperature of $-20^{\circ} \mathrm{C}$, save for later or proceed to extract nucleic acid directly.

\subsection{Real-Time Fluorescent PCR Reaction}

Reverse transcription: add the following substance in eppendorf tubes in sequence: $10 \times$ Reverse transcriptase buffer $(200 \mathrm{mM}$ Tris/HCl, $\mathrm{pH}$ 8.4, and 500 $\mathrm{mM} \mathrm{KCl}), 2 \mu \mathrm{L}$; reverse primer $4 \mu \mathrm{L}$; dNTPs $(10 \mathrm{mM}$ each dATP, dCTP, dGTP, dTTP), $2 \mu \mathrm{L} ; \mathrm{MgCl}_{2}(25 \mathrm{mM}) 2.0 \mu \mathrm{L}$; DTT $(0.1 \mathrm{M}) 2.0 \mu \mathrm{L}$; AMV reverse transcriptase (200 units $/ \mu \mathrm{L}$ ), $0.5 \mu \mathrm{L}$, add water to $20 \mu \mathrm{L}$, perform short spin, $95^{\circ} \mathrm{C} 10$ $\min , 45^{\circ} \mathrm{C} 40$, proceed to PCR immediately or save at $-20^{\circ} \mathrm{C}$ for later use.

Fluorescent PCR reaction system $(25 \mu \mathrm{L}$, nucleic acid template $5 \mu \mathrm{L}): 10 \times$ PCR buffer solution, $2.5 \mu \mathrm{L} ; 2.5 \mathrm{mmoL} / \mathrm{L} \mathrm{MgCL}_{2} 5 \mu \mathrm{L} ; 10 \mathrm{mmol} / \mathrm{L}$ DNTP 0.75 $\mu \mathrm{L}, 10 \mu \mathrm{mol} / \mathrm{L}$ cross dimer $1 \mu \mathrm{L}, 5 \mu \mathrm{mol} / \mathrm{L}$ probe $1 \mu \mathrm{L}, 0.5 \mu \mathrm{L}$ Taq enzyme $(2 \mathrm{U} / \mu \mathrm{L})$, DNA $2 \mu \mathrm{L}$ complement $25 \mu \mathrm{L}$ system with DEPC water. Amount of premixed reaction fluid to be prepared $=$ sample number + contrast number +1 [2]: Draw each kind of reagent into microcentrifuge by amount of usage, mix 
properly and load $25 \mu \mathrm{L}$ into each PCR optick tube.

\subsection{RNA Extraction}

Methods: Take $100 \mathrm{mg}$ tissue samples and cut into pieces, add $0.01 \mathrm{~mol} / \mathrm{L} \mathrm{Ph}$ 7.6PBS by 1:5, repeat freezing and thawing for three times after grinding, centrifugateat $4{ }^{\circ} \mathrm{C} 12,000 \mathrm{r} / 5 \mathrm{~min}$ and take the supernatant, preserve at $-20^{\circ} \mathrm{C}$, save for later use and proceed to extract nucleic acid directly;

Soak all RNA extraction vessels in DEPC water for $24 \mathrm{~h}$ and sterilize before use. Add $1 \mathrm{~mL}$ Trizollysate to the sample before completing the before-mentioned procedure and place aside for $5 \mathrm{~min}$ at room temperature. Add $0.2 \mathrm{~mL}$ of trichloromethane, ocilliate violently for $15 \mathrm{~s}$, and place aside for $3 \mathrm{~min}$ at room temperature, centrifuge at $4^{\circ} \mathrm{C} 12,000 \mathrm{r} / 15 \mathrm{~min}$. Take Eppendorf tube out, gently remove supernate and place upsidedown on absorbent paper, with different samples soaked with different parts on the paper;

Add $20 \mu \mathrm{L}$ sterilization DEPC water to each tube, mix gently till RNA on the tube wall begin to dissolve, centrifuge at $2000 \mathrm{r} / \mathrm{min}$ for $5 \mathrm{~s}$ and save on ice for later use. The extracted RNA should be amplified by RT-PCR within $2 \mathrm{~h}$ or placed in refrigerator at $-70^{\circ} \mathrm{C}$ for later use.

In the process of extracting RNA, both methods of DNA chloroform extraction and commercialized genomic DNA extraction kit are adopted to full genetic DNA of the virus, and no distinction is proved to be found.

\section{Results and Discussion}

\subsection{Building of Fluorescent Quantitative PCR Method}

In order to obtain minimum Ct value, the typical fluorescence amplification curve and high fluorescence intensity primers and probe optimum concentration, and according to Table 1 and Table 2, we determine the extraction virus and select four groups of concentration as follows: $40 \mathrm{ng} / \mathrm{mL}, 60 \mathrm{ng} / \mathrm{mL}, 80$ $\mathrm{ng} / \mathrm{mL}$ and $100 \mathrm{ng} / \mathrm{mL}$. As shown in Figure 1, select $80 \mathrm{ng} / \mathrm{mL}$ as the nucleic acid concentration.

\subsection{Specificity Test}

Fluorescence quantitative PCR method is applied in detecting Epizootic

Table 1. Reverse transcription reaction system (General system $20 \mu \mathrm{L}$ ).

\begin{tabular}{cc}
\hline $10 \times$ Reverse transcriptase buffer & $2 \mu \mathrm{L}$ \\
\hline MgCL2 $(25 \mathrm{mmol} / \mathrm{L})$ & $2 \mu \mathrm{L}$ \\
dNTPs $(10 \mathrm{mM})$ & $2 \mu \mathrm{L}$ \\
DTT $(0.1 \mathrm{M})$ & $2 \mu \mathrm{L}$ \\
reverse primer $(10 \mathrm{umol} / \mathrm{L})$ & $4 \mu \mathrm{L}$ \\
AMV Reverse transcriptase $(200$ units $/ \mu \mathrm{l})$ & $0.5 \mu \mathrm{L}$ \\
$\operatorname{ddH}_{2} \mathrm{O}$ & $7.5 \mu \mathrm{L}$ \\
\hline
\end{tabular}


Table 2. Real-time PCR reaction system (General system $25 \mu \mathrm{L}$ ).

\begin{tabular}{cc}
\hline $10 \times \operatorname{PCR}_{\text {buffer solution }}$ & $2.5 \mu \mathrm{L}$ \\
\hline $\mathrm{MgCL}_{2}(2.5 \mathrm{mmol} / \mathrm{L})$ & $5 \mu \mathrm{L}$ \\
$\operatorname{dNTPs}(10 \mathrm{mM})$ & $2 \mu \mathrm{L}$ \\
forward primer $(10 \mathrm{umol} / \mathrm{L})$ & $1 \mu \mathrm{L}$ \\
reverse primer $(10 \mathrm{umol} / \mathrm{L})$ & $1 \mu \mathrm{L}$ \\
probe $(5$ umol/L) & $1 \mu \mathrm{L}$ \\
DNA & $2 \mu \mathrm{L}$ \\
Taqenzyme $(2 \mathrm{U} / \mu \mathrm{L})$ & $0.5 \mu \mathrm{L}$ \\
$\operatorname{ddH}_{2} \mathrm{O}$ & $10 \mu \mathrm{L}$ \\
\hline
\end{tabular}

Reaction condition: Phase 1, denaturation $95^{\circ} \mathrm{C} 5 \mathrm{~min}$, reverse transcription $45^{\circ} \mathrm{C} 40 \mathrm{~min}$; Phase 2, predegeneration $95^{\circ} \mathrm{C} 5 \mathrm{~min}$; Phase $3,95^{\circ} \mathrm{C} 30 \mathrm{~s}, 60^{\circ} \mathrm{C} 1 \mathrm{~min}, 40$ circulation.

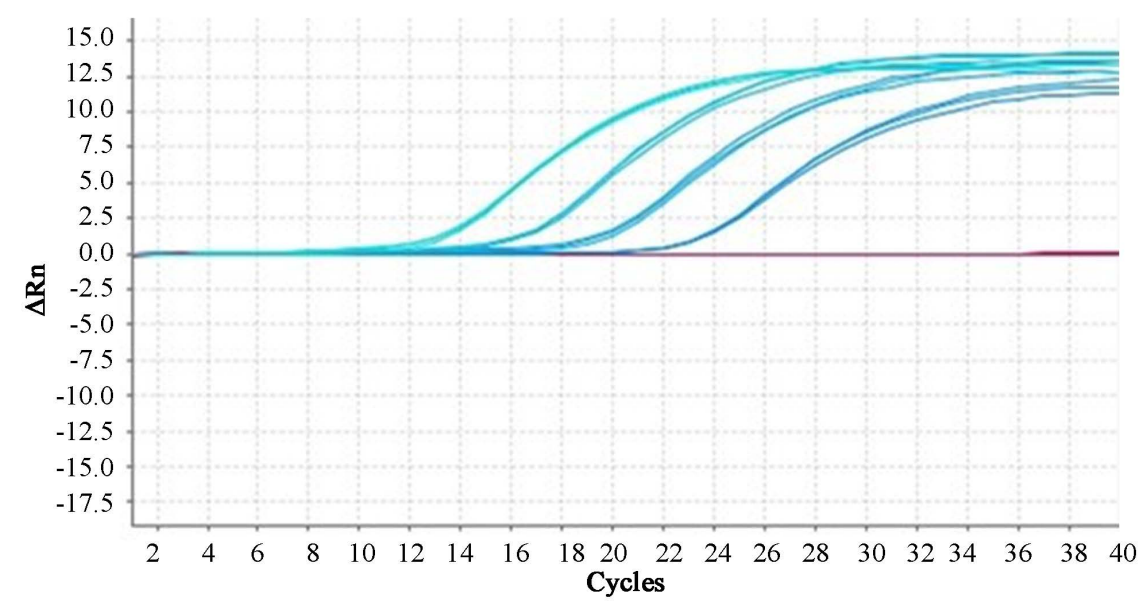

Figure 1. The establishment of the reaction procedure. Remarks: the abscissa is the number of cycles and the ordinate is the quantity of the PCR product.

hemorrhagic disease of deer virus, bluetongue virus, deer epidemic hemorrhagic disease virus, mycobacterium tuberculosis, bovine mucous diarrheas disease virus and foot and mouth disease virus, with $\mathrm{DdH} 2 \mathrm{O}$ as a negative contrast to detect the specificity of primers and probes (see Figure 2).

\subsection{Sensitivity and Reproducibility Test}

Test sensitivity of fluorescence quota PCR examination by serial diluting nucleic acid for 10 times. Perform 3 repeated fluorescence PCR tests on 4 different dilutions of the same positive sample to evaluate reproducibility of this method by the fluorescence amplification curve repetition and $\mathrm{Ct}$ value variation within and between groups. Results see Figure 3, Figure 4.

\subsection{Clinical Sample Detection}

Take 80 test samples and compare test results to known results, and the coincidence rate turns out to be $100 \%$. 


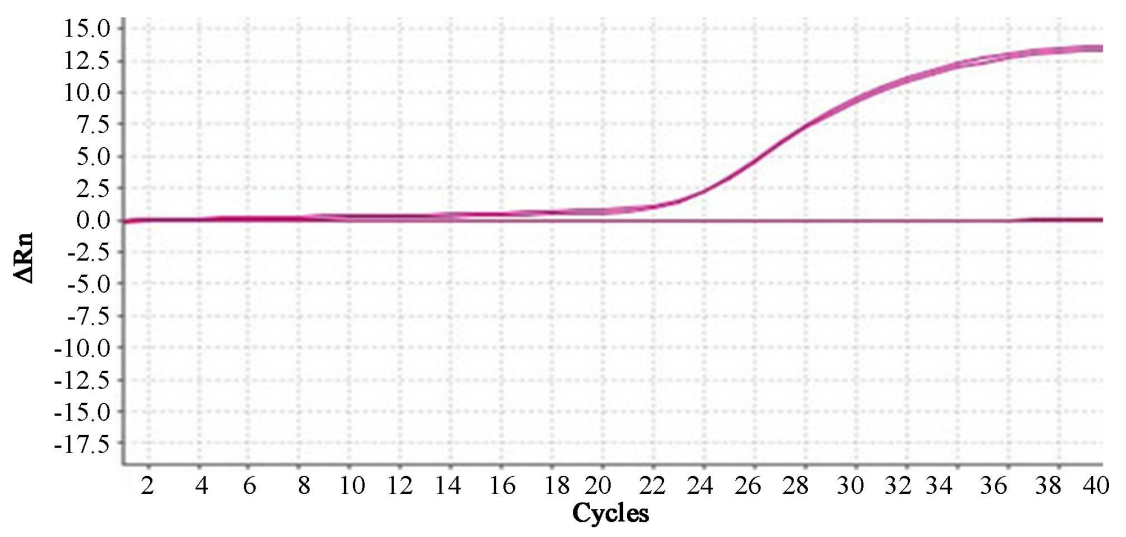

Figure 2. Specificity Test. Remarks: the abscissa is the number of cycles and the ordinate is the quantity of the PCR product.

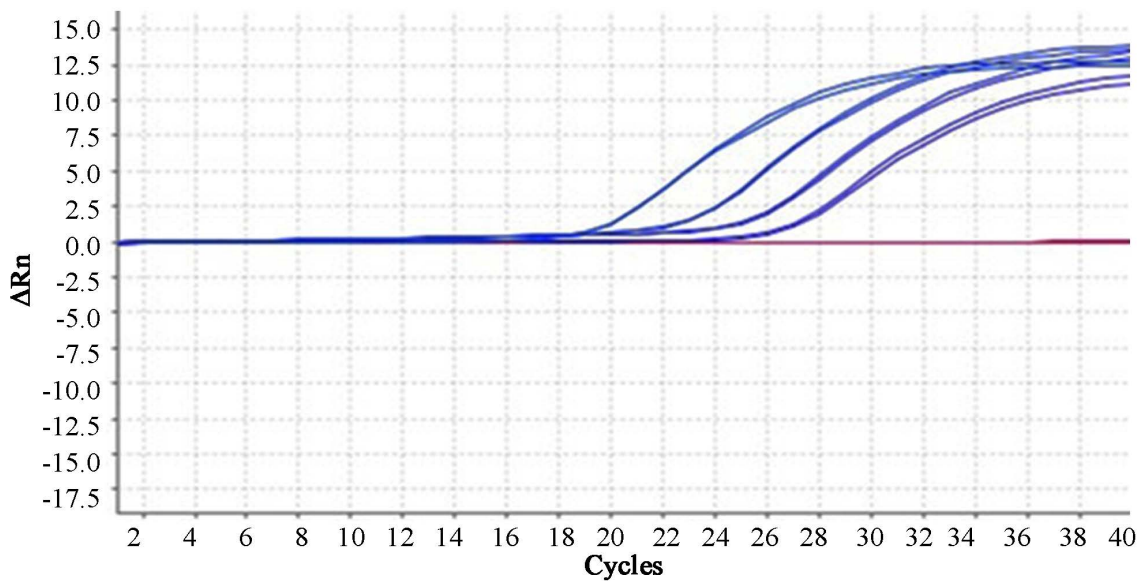

Figure 3. Sensitivity test. Remarks: the abscissa is the number of cycles and the ordinate is the quantity of the PCR product.

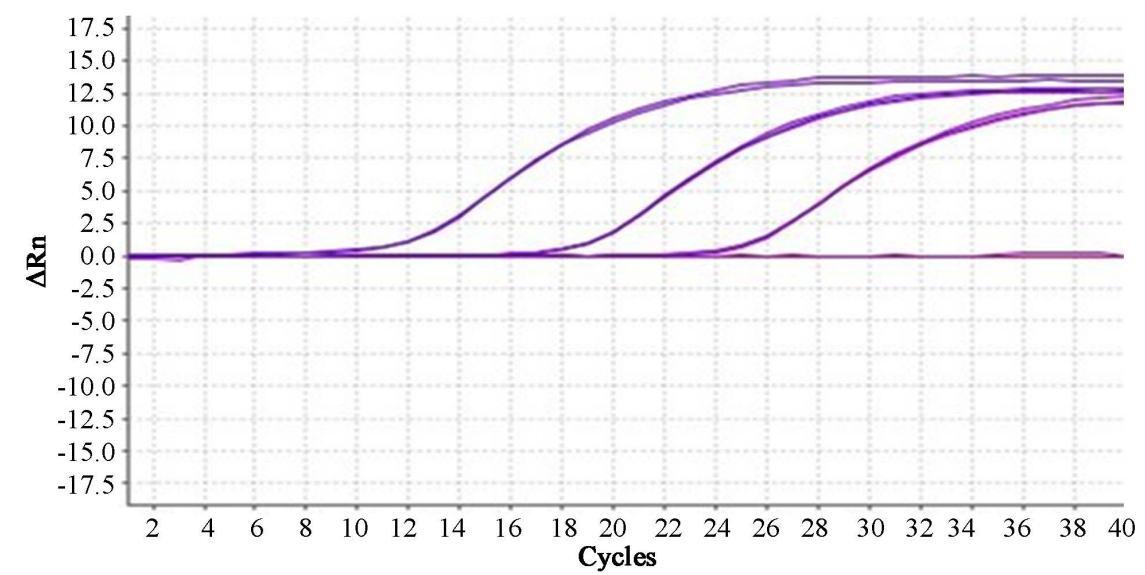

Figure 4. Reproducibility test. Remarks: the abscissa is the number of cycles and the ordinate is the quantity of the PCR product.

\section{Conclusion}

In this paper, TaqMan method was used to compare the nucleotide sequence of 
$S$ gene of EDHV genome. Specific primers and specific fluorescent double labeling probes were designed for pairing. Probe 5 ' labeled FAM fluorescent was a reported fluorescent group (expressed in R). 3' labeling of TAMRA fluorescent as quenching Group (expressed as Q), it could absorb the fluorescence signal of 5 ' fluorescence gene in short distance. When the PCR reaction entered the annealing stage, the primers and probes combined with the target gene fragment simultaneously. At this time, the fluorescence signal from the $\mathrm{R}$ group on the probe was absorbed by the $\mathrm{Q}$ gene, but the fluorescence signal could not be detected by the instrument. And when the reaction reaches the extension stage, the 5' to 3' exonuclease function of the Taq-enzyme degrades the probe. In this way, the $\mathrm{R}$ group on the probe is dissociated, and the fluorescence emitted by the probe is no longer absorbed by $\mathrm{Q}$ and is received by the detector. With the cycle of PCR reaction, the relationship between the product of PCR and the growth of fluorescence signal appears to be corresponding. Then real-time fluorescence quantitative PCR can be used in quantitative determination and has been widely applied in many other fields [3].

\section{Conflicts of Interest}

The authors declare no conflicts of interest regarding the publication of this paper.

\section{References}

[1] Ruan, Z.X., Yang, J.X., et al. (2010) Establishment of Multiple RT-PCR Detection Method for Four Animal Insect-Borne Viruses. Advances in Animal Medicine, No. 2, 25-31.

[2] Jia, J.J. and Li, W.G. (2003) PCR Technique Was Used to Detect Deer Epidemic Hemorrhage Virus. Animal Husbandry and Veterinarian, 35, 24-26.

[3] Chen, J.C., et al. (2010) Establishment of a Real-Time Fluorescent PCR Method for Rapid Detection of Deer Epidemic Hemorrhage Virus. Modern Journal of Integrated Chinese and Western Medicine, 19, 156-158. 